\title{
Effect of Menstrual Cycle and Different Age on Vaginal Microflora of Healthy Women
}

\author{
Tomohiko Fujisawa, ${ }^{1}$ Yoshimi Benno ${ }^{2}$ and Tomotari Mrtsuora ${ }^{1,3}$ \\ 1 Frontier Research Program, ${ }^{2}$ Japan Collection of Microorganisms, \\ RIKEN, Wako, Saitama 351-01 and \\ ${ }^{3}$ Nippon Veterinary and Animal Science University, \\ Musashino, Tokyo 180
}

(Received for publication, March 9, 1992)

\begin{abstract}
The composition of vaginal microflora of forty healthy women whose ages ranged from 20 to 50 years (menstrual cycle: estrogenic phase, 15 persons; luteal phase, 25 persons) was anaerobically and aerobically determined. The total numbers in the vaginal specimens obtained from all the subjects were approximately $10^{9}$ $\mathrm{CFU} / \mathrm{g}$ of vaginal secretions. Numbers of anaerobic bacteria in the vaginal specimens were higher than those of aerobic bacteria. Lactobacilli were the predominant microorganisms in the vaginal specimens. The numbers of bacteroides, streptococci, and Gardnerella vaginalis, and incidences of staphylococci and peptostreptococci were increased with aging whereas the numbers of lactobacilli decreased with aging.
\end{abstract}

Key words : aging; menstrual cycle; vaginal microflora

The vaginal microflora has interested many investigators $(1,3,7,10)$ to recognizing of its significant association with vaginal tract infection. Early studies on the vaginal microflora utilized the stained smears of vaginal secretions, because the taxonomic guidlines were limited and cultural methods were incomplete. In the late 1800s, some workers thought that "Doderlein's bacilli" were the main microorganisms in the vagina. With subsequent studies and improved methods for culture and differentiation of bacteria, numerous bacterial species were detected as common or infrequent members of the vaginal microflora $(16,20)$.

Yeasts or Trichomonas vaginalis as pathogens of the vagina and cervix vaginalis have been commonly recognized. Recently, Chlamydia trachomatis has been established as one of the causes of vaginal discharge (21). On the other hand, disease state belonging to the category commonly known as nonspecific vaginitis (NSV) also exists $(6)$. The term "NSV" is used to describe the vaginitis of which specific etiological agents (the genera of Candida, Trichomonas, and Chlamydia) cannot be demonstrated. Although many investigators have studied the cause of NSV, this problem has not yet been solved. To understand the pathogenesis of NSV, there- 
fore, a closer look at the vaginal microflora in healthy women is required.

The present study was undertaken to analyze the quantitative and qualitative compositions of vaginal microflora in healthy women and to determine the effects of menstrual cycle and age on the human vaginal microflora.

\section{MATERIALS AND METHODS}

Volunteers. Vaginal secretions were collected with a sterile sponge from 40 healthy women aged 20 to 50 years. Of fourty vaginal specimens, 15 samples were collected on the estrogenic phases from the end of menstruation to the 10th day after the end of menstruation and the remaining 25 samples were collected on the luteal phase from the 11 th day after the end of menstruation to the beginning of menstruation.

Collection of vaginal specimens. The sterile sponge was weighed before use. After the sample processing, the sponges absorbing vaginal fluid were placed into a sterile transport medium (14) filled with $100 \% \mathrm{CO}_{2}$ gas atmosphere. Samples sealed into the medium were kept at $4^{\circ} \mathrm{C}$ until processed. Sample weight was determined by subtracting the combined weight of the tubes, buffer, and sterile sponge.

Culture media and methods. The method for bacterial analysis of the vaginal microflora in this study was essentially the same as that of Mitsuoka et al (13). After thorough mixing, a series of 10 -fold dilutions $\left(10^{-1}\right.$ to $\left.10^{-7}\right)$ was made in anaerobic diluents (12). From appropriate dilutions, $0.05 \mathrm{ml}$ aliquots were spread onto three non-selective agars: modified Eggerth-Gagnon (EG) agar for anaerobes (13); glucose liver blood (BL) agar for anaerobes (13); trypticase soy blood (TS) agar (BBL Microbiology Systems, Cockeysville, Md.) for aerobes (13), as well as eleven selective agars: bifidobacteria selective (BS) agar for bifidobacteria (13); eubacteria selective (ES) agar for eubacteria (12); neomycin-brilliant greentaurocholate-blood (NBGT) agar for bacteroides (13); neomycin-Nagler (NN) agar for lecithinase-positive clostridia (13); modified veillonella selective (VS) agar for veillonellae and megasphaerae (13); modified lactobacilli selective (LBS) agar for lactobacilli (13), peptone-starch-glucose (PSG) agar for Gardnerella vaginalis (4); triphenyltetrazolium chloride-acridine orange-thallous sulfate-aesculincrystal violet (TATAC) agar for enterococci and streptococci (13); phenylethyl alcohol egg yolk suspension (PEES) agar for staphylococci and micrococci (13); potate dextrose (PD) agar (Difco, Detroit) for yeasts and molds (13); and deoxycholate hydrogen sulfide lactose (DHL) agar (Eiken, Tokyo) for enterobacteria (13). Nine agars (EG, BL, BS, NBGT, ES, NN, VS, LBS, and PSG) were incubated at $37^{\circ} \mathrm{C}$ for 2 days in an anaerobic steel wool jar (19) filled with an atmosphere of oxygen-free $\mathrm{CO}_{2}$. Two agars (TATAC and PEES) were incubated aerobically at $37^{\circ} \mathrm{C}$ for $48 \mathrm{hr}$; TS and DHL agars were incubated at $37^{\circ} \mathrm{C}$ for $24 \mathrm{hr}$.

The isolates from vaginal specimens were identified by Gram stain, colony and cell morphology, aerobic growth, spore formation, and catalase test. For the bacterial species identified, the bacterial count per $g$ of vaginal contents was 
calculated and converted into a logarithmic equivalent. The total viable count was calculated from the sum of the counts of each bacterial species.

\section{RESULTS}

The composition of vaginal microflora of the 40 healthy women employed is shown in Table 1. The total bacterial counts were $10^{9} \mathrm{CFU} / \mathrm{g}$ of vaginal secretions. Lactobacilli were isolated predominantly except for one specimen. Eubacteria and bifidobacteria were also isolated in higher number, but less commonly found than lactobacilli.

The changes of the vaginal microflora during the menstrual cycle are also given in Table 1. Lactobacilli were isolated predominantly throughout both estrogenic and luteal phases. The number of eubacteria was also high during the menstrual cycle. The incidences and the numbers of bacteroides and peptostreptococci were at moderate levels throughout the phases. However, bifidobacteria was found at the luteal phase only.

A relationship between the age and the composition of vaginal microflora is shown in Table 2. The kinds of microorganisms isolated from younger women were less than those of the older ones. Three bacterial groups--bifidobacteria, veillonellae, and enterobacteria-were not isolated from healthy women aged 20 to 29 years. The numbers of bacteroides, eubacteria, staphylococci, streptococci, and $G$. vaginalis, and frequencies of occurrences of staphylococci and peptostrepto-

Table 1. Effect of menstrual cycle on the vaginal microflora of healthy women

\begin{tabular}{|c|c|c|c|c|}
\hline \multirow[b]{2}{*}{ Microflora } & \multirow{2}{*}{\multicolumn{2}{|c|}{$\begin{array}{l}\text { Total } \\
(n=40)\end{array}$}} & \multicolumn{2}{|c|}{ Menstrual cycle } \\
\hline & & & $\begin{array}{l}\text { Estrogenic phase } \\
\quad(n=15)\end{array}$ & $\begin{array}{l}\text { Luteal phase } \\
\quad(n=25)\end{array}$ \\
\hline \multicolumn{5}{|l|}{ Anaerobic bacteria } \\
\hline Bacteroides & $6.5 \pm 2.6^{a}$ & $(58)^{b}$ & $6.4 \pm 3.1(47)$ & $6.5 \pm 2.6(64)$ \\
\hline Eubacteria & $8.6 \pm 2.4$ & $(15)$ & $9.5 \pm 1.2(13)$ & $8.1 \pm 2.8(16)$ \\
\hline Peptostreptococci & $6.4 \pm 2.3$ & (55) & $7.0 \pm 2.3(60)$ & $5.4 \pm 2.2(52)$ \\
\hline Bifidobacteria & $7.4 \pm 2.6$ & (13) & $\leqq 2.0(0)$ & $4.4 \pm 2.6(20)$ \\
\hline Veillonellae & $3.5 \pm 0.3$ & ( 8 ) & $3.3 \pm 0.2(13)$ & $3.8 \quad(4)$ \\
\hline Lecithinase-negative clostridia & 3.0 & ( 3 ) & $\leqq 2.0(0)$ & $3.0 \quad(4)$ \\
\hline Lactobacilli & $9.0 \pm 1.1$ & $(70)$ & $8.5 \pm 1.4(67)$ & $9.2 \pm 1.1(72)$ \\
\hline \multicolumn{5}{|l|}{ Aerobic bacteria } \\
\hline Enterobacteria & $4.4 \pm 1.4$ & $(23)$ & $4.3 \pm 1.5(33)$ & $5.3 \pm 1.9(16)$ \\
\hline Streptococci & $5.6 \pm 2.1$ & $(60)$ & $6.2 \pm 2.3(53)$ & $5.3 \pm 2.0(64)$ \\
\hline Staphylococci & $4.2 \pm 1.1$ & $(55)$ & $4.1 \pm 1.1(53)$ & $4.2 \pm 1.2(56)$ \\
\hline Corynebacteria & $5.6 \pm 1.9$ & $(45)$ & $5.3 \pm 1.5(47)$ & $5.8 \pm 2.2(44)$ \\
\hline Gardnerella vaginalis & $6.7 \pm 1.9$ & (33) & $6.8 \pm 1.9(27)$ & $6.7 \pm 2.1(36)$ \\
\hline Yeasts & $6.5 \pm 2.1$ & (23) & $5.0 \pm 0.3(13)$ & $7.0 \pm 2.2(28)$ \\
\hline Total bacteria $^{c}$ & $9.4 \pm 0.9$ & & $8.9 \pm 1.2$ & $9.5 \pm 0.8$ \\
\hline
\end{tabular}

$a$ Mean $\pm \mathrm{SD}$ of $\log$ bacterial counts/g of vaginal specimens.

$b$ Frequencies of occurrences (\%).

c Megasphaerae, lecithinase-positive clostridia, and bacilli were detected $(\leqq 2.0)$. 
Table 2. Effect of aging on the vaginal microflora of healthy women

\begin{tabular}{|c|c|c|c|}
\hline \multirow[b]{2}{*}{ Microflora } & \multicolumn{3}{|c|}{ Age } \\
\hline & $\begin{array}{c}20-29 \text { years } \\
\text { old }(n=7)\end{array}$ & $\begin{array}{l}30-39 \text { years } \\
\text { old }(n=18)\end{array}$ & $\begin{array}{l}40-50 \text { years } \\
\text { old }(n=15)\end{array}$ \\
\hline \multicolumn{4}{|l|}{ Anaerobic bacteria } \\
\hline Bacteroides & $6.0 \pm 2.8 a(57)^{b}$ & $4.8 \pm 2.2(50)$ & $8.1 \pm 2.1(67)$ \\
\hline Eubacteria & $3.9 \quad(14)$ & $9.0 \pm 0.5(11)$ & $9.9 \pm 0.4(20)$ \\
\hline Peptostreptococci & $6.8 \pm 3.5$ & $5.2 \pm 2.1(67)$ & $7.2 \pm 2.1(53)$ \\
\hline Bifidobacteria & $\leqq 2.6 \quad(0)$ & $7.1 \pm 2.9(22)$ & $8.7 \quad(7)$ \\
\hline Veillonellae & $\leqq 2.0 \quad(0)$ & $\leqq 2.0(0)$ & $3.5 \pm 0.3(20)$ \\
\hline Lecithinase-negative clostridia & $\leqq 2.0$ & $3.0 \quad(6)$ & $\leqq 2.0(0)$ \\
\hline Lactobacilli & $9.8 \pm 1.1$ & $8.8 \pm 1.3(67)$ & $8.6 \pm 1.0(67)$ \\
\hline \multicolumn{4}{|l|}{ Aerobic bacteria } \\
\hline Enterobacteria & $\leqq 2.0$ & $4.3 \pm 1.5(33)$ & $4.1 \pm 1.7(20)$ \\
\hline Streptococci & $3.5 \pm 0.3$ & $5.8 \pm 2.0(78)$ & $6.8 \pm 2.4(33)$ \\
\hline Staphylococci & $3.9 \pm 0.3$ & $4.4 \pm 1.5(44)$ & $4.1 \pm 0.9(73)$ \\
\hline Corynebacteria & 3.9 & $5.9 \pm 1.9(50)$ & $5.4 \pm 2.0(53)$ \\
\hline Gardnerella vaginalis & $6.7 \pm 1.9$ & $6.4 \pm 1.9(39)$ & $7.8 \pm 2.2(27)$ \\
\hline Yeasts & $6.6 \pm 0.9$ & $5.8 \pm 2.2(28)$ & $4.0 \quad(7)$ \\
\hline Total bacteria ${ }^{c}$ & $9.7 \pm 1.0$ & $9.1 \pm 1.0$ & $9.4 \pm 0.9$ \\
\hline
\end{tabular}

a Mean \pm SD of log bacterial counts/g of vaginal specimens.

$\checkmark$ Frequencies of occurrences (\%).

c Megasphaerae, lecithinase-positive clostridia, and bacilli were detected ( $\leqq 2.0)$.

cocci were increased with age, whereas the numbers and incidences of lactobacilli were not increased with age.

\section{DISCUSSION}

Although quantitative studies on the vaginal microflora of healthy women have been reported by several workers $(1,2,9,10)$, the small amount of vaginal secretion raises the question of sampling error. Bartlett et al (1) reported that the discrepancy of the composition of vaginal microflora was responsible for the difference of the recovery of total bacteria. Onderdonk et al (17) indicated that $10^{9}-10^{10}$ bacteria per $\mathrm{ml}$ of vaginal specimen may be expected in the vaginal specimens. The results in the present study indicate that vaginal microflora of healthy women with a normal menstrual cycle tended to be constant and total bacterial counts averaged $10^{9}$ per $\mathrm{g}$ of vaginal secretions. Lactobacilli was isolated from the vaginal specimens as the predominant microorganism in the present study. If the number of lactobacilli decreased in the vagina, other microorganisms, such as bacteroides and/or eubacteria occurred in large numbers $\left(10^{8}-10^{9}\right)$. Thus, lactobacilli in the vagina may be related to the stability of resident vaginal microflora.

Bartlett et al (2) showed the changes in the vaginal microflora during the menstrual cycle and showed that aerobic bacteria increased during menstruation. Some workers $(2,8,18)$ have proposed that changes in $\mathrm{pH}$, cellular content, hormonal and biochemical conditions of the vagina may be related to the changes of 
the vaginal microflora during the menstrual cycle. Advanced age may also influence the change of hormonal secretions. Therefore, further studies are needed to confirm the relationship among the changes of the vaginal microflora at the species level, the menstrual cycle, and aging.

Gardner et al (5) reported that G. (Heamophilus) vaginalis is closely associated with bacterial vaginosis, which occasionally causes invasive diseases such as endometritis, amnionitis, and bacteremia $(11,15)$. It has been reported that this organism is often present in the vaginal flora as a potential pathogen (20). In the present study, G. vaginalis was recovered from 13 of 40 healthy women (33\%).

The relationships between age and the composition of the vaginal microflora of healthy women have not been reported earlier. The findings in this study indicated that the incidence and number of lactobacilli in younger women were higher than that of older women. On the contrary, the number of G. vaginalis in younger women was lower than that of older women.

If the vaginal specimens are cultured anaerobically as a routine, the role of anaerobic bacteria in the vaginal microflora will be elucidated. It has been reported that the increasing prevalence of bacteroides and peptostreptococci indicates a disturbance of the normal flora (10). A difference on the numbers of bacteroides between younger women aged 20-29 years and older women aged 40-50 years was noted. We consider that these findings may be useful for the study of relationships between incidences of NSV and aging.

\section{REFERENCES}

(1) Bartlett, J.G., N.E. Moon, P.R. Goldstein, B. Goren, A.B. Onderdonk, and B.F. Polk. 1978. Cervical and vaginal bacterial flora: ecologic niches in the female lower genital tract. Am. J. Obstet. Gynecol. 130: 658-661.

(2) Bartlett, J.G., A.B. Onderdonk, E. Drude, C. Goldstein, M. Anderka, S. Alpert, and W.M. McCormack. 1977. Quantitative bacteriology of the vaginal flora. J. Infect. Dis. 134: 271-277.

(3) Corbishley, C.M. 1977. Microbial flora of the vagina and cervix. J. Clin. Pathol. 30: 745-748.

(4) Dunkelberg, W.E., Jr., R. Skaggs, and D.S. Kellogg. 1970. Method for isolation and identification of Corynebacterium vaginale (Haemophilus vaginalis). Appl. Microbiol. 19: 47-52.

(5) Gardner, H.L. 1980. Haemophilus vaginalis vaginitis after twenty-five years. Am. J. Obstet. Gynecol. 137: 385-390.

(6) Gardner, H.L., and C.D. Dukes. 1955. A newly defined specific infection previously classified "non-specific vaginitis." Am. J. Obstet. Gynecol. 69: 962-976.

(7) Gupta, U., A. Oumachigui, and V. Hingrorani. 1973. Microbial flora of the vagina with special references to anaerobic bacteria and mycoplasma. Indian J. Med. Res. 61: 1600-1603.

(8) Larsen, B., and R.P. Galask. 1980. Vaginal microbial flora: practical and theoretic relevance. Obstet. Gynecol. 55: 100S-113S.

(9) Levison, M.E., L.C. Corman, E.R. Carrington, and D. Kaya. 1977. Quantitative microflora of the vagina. Am. J. Obstet. Gynecol. 127: 80-85.

(10) Linder, J.G.E.M., F.H.F. Plantema, and J.A.A. Hoogkamp-Korstanje. 1977. Quantitative studies of the vaginal flora of healthy women and of obstetric and gynaecological patients. J. Med. Microbiol. 11 : 233-241.

(11) Masfari, A.N., B.I. Deurden, and G.R. Kinghorn. 1986. Quantitative studies of vaginal bacteria. Genitourin. Med. 62: 256-263. 
(12) Mitsuoka, T., K. Ohno, Y. Benno, K. Suzuki, and K. Namba. 1976. Die Faekalflora bei Menschen. IV. Mitteilung: Vorgleich des neu entwickelten Verfahrens mit dem bisherigen . ublichen Verfahren zur Darmfloraanalyse. Zentralbl. Bakteriol. Hyg., I. Abt. Orig. A234: 219-233.

(13) Mitsuoka, T., T. Sega, and S. Yamamoto 1965. Eine verbesserte Methodik der qualitativen und quantitativen Analyse der Darmflora von Menschen und Tieren. Zentralbl. Bakteriol. Parasitenkd. Infektionskr. Hyg. I Abt. Orig. A195: 455-469.

(14) Mitsuoka, T., A. Terada, and Y. Morishita. 1973. Die Darmflora von Mensch und Tier. Goldschmidit informiert. 23: 23-41.

(15) Monif, G.R.G., and H. Bear. 1974. Haemophilus (Corynebacterium) vaginalis septicemia. Am. J. Obstet. Gynecol. 120 : 1041-1045.

(16) Nearly, M.P., J. Allen, O.A. Okubadejo, and D.J.H. Payne. 1977. Preoperative vaginal bacteria and postoperative infections in gynecological patients. Lancet ii: 1291-1294.

(17) Onderdonk, A.B., B.F. Polk, N.E. Moon, D. Goren, and J.G. Bartlett. 1977. Methods for quantitative vaginal flora studies. Am. J. Obstet. Gynecol. 128: 777-781.

(18) Onderdonk, A.B., G.R. Zamarchi, M.L. Rodriguez, M.L. Hirsch, A. Munoz, and E.H. Kass. 1987. Qualitative assessment of vaginal microflora during use of tampons of various compositions. Appl. Environ. Microbiol. 53: 2779-2784.

(19) Parker, C.A. 1955. Anaerobiosis with iron wool. Aust. J. Biol. Sci. 33: 33-37.

(20) Sautter, R.S., and W.J. Brown. 1980. Sequential vaginal cultures from normal young women. J. Clin. Microbiol. 11 : 479-484.

(21) Sevesson, L., L. Westrom, and P.A. Mardh. 1981. Chlamydia trachomatis in women attending a gynaecological and patient clinic with lower genital tract infection. Br. J. Vener. Dis. 57: 259-262. 